\section{The Musyrif Guidance Program In Boarding School At Middle School}

\author{
Aldi Muhammad Thoha ${ }^{1}$, Imas Kania Rahman ${ }^{2}$, Ibdalsyah ${ }^{3}$ \\ 1,2,\&3 Sekolah Pascasarjana, Universitas Ibn Khaldun Bogor, Indonesia \\ *aldimbubammad_thoha@yahoo.com
}

\begin{abstract}
The management of the boarding school counseling program at the middle level that is not organized and structured will impact on students, including those who are not at home in the dormitory, commit violations, and do not have Islamic customs. this is caused by the lack of responsibility of a musyrif in managing students in the dormitory, this requires maximum assistance and good services in the form of providing guidance programs in producing professional and responsible musyrif. This research aims to find out the best musyrif guidance program in secondary level boarding schools. The approach used in this research is descriptive qualitative By using themethod field research, data collection techniques carried out were observation, interviews, open questionnaires and documents. The formulation of musyrif and musyrifah guidance programs in Boarding School secondary schools was validated through focus group discussions (FGD) involving four experts namely guidance and counseling experts, Islamic religious experts, caretakers of Islamic boarding schools, and linguists. The results of this study indicate that the musyrif and musyrifah guidance programs at boarding schools at the secondary level are arranged based on program components, such as basic services, reponsive services, individual planning and system support. The guidance material consists of leadership, manners, achievement motivation, decision making skills, diversity of characters and cultures, parenting and responsibilities.
\end{abstract}

\section{Abstrak}

Pengelolaan program bimbingan musyrif dan musyrifah boarding school ditingkat menengah yang tidak terorganisir dan terstruktur akan berimbas pada peserta didik diantaranya tidak betah di asrama, melakukan pelanggaran, dan tidak memiliki adab Islami. Hal ini menuntut adanya pendampingan maksimal dan layanan yang baik berupa pembekalan program bimbingan dalam menghasilkan musyrif dan musyrifah yang profesional dan bertanggungjawab. . Hal ini disebabkan karena kurangnya tanggung jawab. Penelitian ini bertujuan untuk mengetahui program bimbingan musyrif terbaik di pesantren tingkat menengah. Pendekatan yang digunakan dalam penelitian ini adalah deskriptif kualitatif. Dengan menggunakan metode penelitian lapangan, teknik pengumpulan data yang dilakukan adalah observasi, wawancara, angket terbuka dan dokumen. Penyusunan program bimbingan musyrif dan musyrifah di sekolah menengah Pesantren divalidasi melalui FGD yang melibatkan empat orang ahli yaitu ahli bimbingan dan konseling, ahli agama Islam, pengurus pondok pesantren, dan ahli bahasa.

\section{Article Information:}

Received July 16, 2020

Revised November 20, 2020

Accepted December 20, 2020

Keywords: musyrif guidance program; boarding school; middle school

Kata Kunci: program pembinaan musyrif; sekolah berasrama; sekolah menengah

\footnotetext{
How to cite: Thoha, A. M., Rahman, I. K., \& Ibdalsyah, I. (2020). The Musyrif Guidance Program In Boarding School At Middle School. Prophetic Guidance and Counseling Journal, 1(2). doi: 10.32832/pro-gcj.v1i2.3220 E-ISSN: 2614-1566

Published by: LPPM Universitas Ibn Khaldun Bogor \& Program Studi BKPI UIKA
} 
Hasil penelitian ini menunjukkan bahwa program bimbingan musyrif dan musyrifah di pesantren tingkat menengah disusun berdasarkan komponen program, seperti pelayanan dasar, pelayanan reponif, perencanaan individu dan dukungan sistem. Materi bimbingan terdiri dari kepemimpinan, budi pekerti, motivasi berprestasi, keterampilan mengambil keputusan, keragaman karakter dan budaya, pola asuh dan tanggung jawab.

\section{Introduction}

Qur'an and hadith as a source of knowledge that implements monotheism as a foundation in behavior and become the main force of humans in achieving success in the revival of Islam in personal life systemsand social.

The emergence of Islamic counseling guidance is inseparable from the problems faced by humans. Every human being is born holy and clean from negative worldly sins and taints that can affect his physical, mental and spiritual structure.

Parents, teachers, communities and relatives in the social environment that are directly or indirectly related are very influential in the process of forming knowledge, behavior and even religion that is adhered to by humans. The Prophet's hadith. "Every human being is born in a state of nature, it is his parents who make him Jewish, Christian and majus" (HR. Bukhori). The influence that arises from society can take the form of religion, philosophy, and the institutionalized culture in it. (Abas Mansur Tamam, 2019)

As the impact of the current era of globalization which has an impact on the order of social life with the majority of the community is more eroded to an understanding that is far from the scope of Islamic education. Influence arising from society can take the form of religion, philosophy, and culture that is institutionalized in it (Nata, 2016)

Guidance and counseling is not only needed by students, educators as figures have a heavy duty and burden in guiding students, so educators need to get guidance and maximum service in dealing with problems related to themselves or with students, families, and the environment.

In this research, it is illustrated that, a boarding school or boarding school school is an educational tool that requires the formation of students who are independent, have character and are able to develop as human beings to grow optimally in accordance with their duties and responsibilities. This requires supervision in accordance with the needs of students in the dormitory, schools with a boarding school system have multiple roles and functions in shaping the maturity of students in learning and developing their maturity.

On this basis boarding schools are required to supervise students for 24 hours straight, starting from students waking up to before going back to sleep. The duties and responsibilities of the supervision are borne by the boarding trustees or boarding supervisors or musyrif who have the rights and obligations in guiding and supervising foster children who become trustees or entrusted their biological parents to make their children learn independently and look for themselves outside the boundaries of the caregivers of their biological parents alone. a good and professional musyrif should be fostered by providing a training program in the form of guidance and services that can improve the work ethic of the musyrif while in the dormitory.

The management of the musyrif guidance program is a must for institutions in creating qualified and competent musyrif in their fields. It is intended that the musyrif be able to carry 
out the mandate assigned and responsible for the problems that occur relating to himself, family, students, and the environment in the hostel.

From the description above, the writer is interested in discussing it in a thesis entitled "Consultative Guidance Program at Boarding School Middle Level".

\section{Literature Review}

\section{A. Understanding Guidance and Counseling}

Iterms of guidance and counseling, interpreted in professional literature in Indonesia, is a translation of the word guidance and counseling in English. In the English dictionary, guidance is conveyed with origin instructions, guides are interpreted: pointing the way, leading, guiding, giving directions, giving, directing and giving advice. (Ramayulis, 2016)

Guidance in terms is a process of providing continuous and systematic assistance to individuals in solving problems they face, in order to achieve the ability to be able to understand themselves, accept themselves, direct themselves and realize themselves in accordance with their potential or ability to achieve adjustment themselves with their environment, both families, schools and communities. (Masdudi, 2008)

Based on the description above it can be concluded that guidance and counseling is a process or effort to provideassistance primary carried out by a counselor or teacher of guidance and counseling to each individual, so that the individual can solve their own problems and assist the individual in developing optimal potential.

\section{B. Understanding Islamic Guidance and Counseling}

Based on Arabic literature the word counseling is called Al-Irshad taken from the word arsyada-yursyidu-Ershadan, and the word guidance is called Attaiujih. Therefore. Guidance and Counseling is translated as Attaujih wa al-irsyad or at-taujih wa al-istisyarah. Etymologically the word Ershad means alhuda, ad-dalah which in Indonesian means, instructions, while the word Al-Istisyarah means talaba min al-mansurah or annasihah, in Indonesian means asking for advice or consultation. (Anwar, 2019)

This can be seen in accordance with the word of Allah SWT. In Suart Al-Kahf verse 10:

It means: "(remember) when the youths sought refuge in the cave, then they prayed:" O our Lord, give us mercy from your side and complete us with righteous guidance in our affairs (this). "

Thohari Musnamar defines Islamic guidance and counseling as a process of providing assistance to individuals to be able to live in harmony with the provisions of Allah. So as to achieve world happiness and the hereafter (Anwar, 2019)

In the Islamic Shari'a it has been taught that educating and guiding children is an obligation for a Muslim because children are a mandate that must be accounted for by parents. This statement is in accordance with the Hadith of the Prophet Muhammad:

"Every baby is born in a sacred state (Islamic nature). Father and mother would later make him Jewish, Christian or Majusi (idol worshiper)"(HR. Bukhari) (Trim, 2008)

Thus, the nature of guidance and counseling in Islam is to direct each individual to have physical or mental health, have aklakul karimah , and able to develop various potentials they have, so that each individual is able to achieve his life's goals by hoping for world happiness and the hereafter 


\section{The Guidance and Counseling}

Program Program is a plan of activities that is prepared operationally by considering the factors related to Guidance and Counseling in Schools in the form of concepts, theory, and application in the form of its implementation. These factors include input consisting of aspects of objectives, types of activities, personnel, time, techniques or strategies, implementation, and other facilities. The guidance program is a series of activities that are systematically carried out in an effort to help students understand themselves and their environment. (Susanto, 2018) The

Program is a structured and organized activity design that is based on a plan, monithoring and evaluation within a predetermined time period.

The structure of the guidance program is classified into four types of services, namely: (1) basic guidance services (2) responsive services, (3) individual planning services, and (4) system support services (Zamroni, 2015).

a. Basic guidance

services This service aims to help the musyrif to get normal development, have a healthy mentality, and obtain basic life skills, or in other words help the musyrif so that they can achieve their developmental tasks.

In detail the service objectives are formulated as an effort to help the musyrif to: (1) have an awareness (understanding) about themselves and their environment (education, work, social culture and religion), (2) be able to develop skills to identify their responsibilities or a set of behaviors that are suitable as an adjustment to their environment, (3) able to handle or meet their needs and problems, and (4) able to develop themselves in order to achieve their life goals.

b. Responsive services Responsive

services are providing assistance to any musyrif who have needs and problems and need immediate help.

Providing assistance to the musyrif who are facing problems and need immediate assistance, so that the musyrif does not experience obstacles in the process of achieving his developmental tasks. Responsive service strategies include individual counseling, group counseling, consultation, collaboration, home visits, and referral.

c. Individual planning

Services Responsive service material depends on problems or consensus needs. The problems and needs of the musyrif are related to the desire to understand something because they are seen as important for positive self-development. Other musyrif problems are related to various things that are experienced or felt to interfere with the comfort of his life or hinder his positive development, because his needs are not met, or fail to achieve his developmental tasks.

Musyrif problems in general are not easy to know directly but can be understood through the behavioral symptoms they display (Zamroni, 2015).

d. Support system

This service is defined as a process of assistance to the musyrif to be able to formulate and carry out activities related to future planning based on an understanding of their strengths and weaknesses, as well as an understanding of the opportunities and opportunities available in their environment. 
Individual planning services aim to help the musyrif so that (1) have an understanding of themselves and their environment, (2) able to formulate goals, planning, or management of their development, both regarding personal, social, learning, and career aspects, and (3) can carry out activities based on the understanding, objectives and plans that have been formulated.

This component is a component of service and management activities, work procedures, infrastructure, such as examples of Information and Communication Technology, and the development of professional skills of counselors or guidance and counseling teachers on an ongoing basis, which indirectly provides assistance to the musyrif or facilitates the smooth development of musyrif and supports the effectiveness and efficient implementation of guidance and counseling services. Included in the activities of this program component is

the musyrif guidance program at boarding school secondary level the author lists four program components related to the guidance and counseling program in general according to western thought and adds to the model of Islamic guidance approaches such as spiritual services.

\section{e. Understanding Mushrifs}

Understanding mushrifs is isim Muzakkar which means overseer, supervising educator or teacher. Musyrif is a person who carries out guidance, in the form of assistance or assistance given to individuals or groups of individuals in avoiding or overcoming various difficulties in their lives, so that individuals or groups of individuals can achieve their welfare. (Herman, 2019)

In general musyrif is a term for boarding guardians who have duties and roles in supervising students in the dormitory for 24 hours, from the musyrif function is educators like teachers in general who are assigned to educate, guide and be a substitute for foster roles of people old.

\section{f. Boarding School Middle}

Boarding school is defined as a boarding school. In a large Indonesian dictionary the dormitory is a temporary residence building for a group of people, consisting of a number of rooms, and is led by a head of the hostel. (Alex, 2013)

Boarding schools are schools with a boarding system, where all students, teachers and school administrators live in a dormitory within the school for a certain period of time.

Secondary education is education that prepares students to become members of the community who have the ability to hold a reciprocal relationship with the socio-cultural environment and natural surroundings, and can develop further abilities in the world of work or higher education. Secondary education, which lasts three years after basic education, is held in high school (senior high school) or equivalent.

\section{Research Methodology}

Research of the musyrif guidance program at boarding schools in the middle level uses descriptive qualitative research, while the type of research is field research or field research carried out intensively, thoroughly, and deeply. Then focused on the object and the subject is musyrif with the aim to find out how the planning, implementation and results of the guidance program carried out on musyrif in boarding schools secondary level. More detailed about the definition of a qualitative approach according to Judith Preissle is: "Qualitative research is a designs or models, all of which are verbal, visual, tactile olfactory, and illustrative data in the form of descriptive narratives such as field notes, videotapes and other written 
records. records and pictures or films. loosely defined category of research or other transcriptions from audio- and video tapes and otheer written records or pictures or films (Putra, 2012).

At this stage of the study the researchers carried out the following steps:

1. Conducting field orientation at SMA-As Syifa Boarding School Subang Wanareja and SMA Insan Cendekia Madani Boarding School Serpong

2. Stages of data collection, using data collection techniques in the form of: a) Field observations in As-Syifa Boarding School Sub-Wanareja Boarding School and Serpong Madani Insan High School Boarding School Serpong, b) Interview with eight informants namely Principal, Principal, Boarding House, Musyrif and Students at As-Syifa SubSchool Boarding School Wanareja Subang and High School Insan Cendekia Madani Boarding School Serpong, c) Documents, analyzing documents related to the guidance program at As-Syifa High School Boarding School Wanareja Subang and High School Insan Cendekia Madani Boarding School Serpong, d)Focus Group Discussion (FGD) in order to validate musyrif guidance programs at boarding schools in secondary level schools by involving four experts namely guidance and counseling experts, experts a Moslems, caretakers of Islamic boarding schools, and linguists

\section{Results And Discussion}

Being aassigned to guide a boarding house is an extraordinary job for a musyrif, and to become a boarding house guardian in a boarding school or school with a system of boarding schools The Boarding School is indeed a very tough challenge, and only people who really want to educate are the ones who want to carry it out, need extraordinary patience, need extraordinary mental endurance, need extraordinary discipline, so the musyrifs are required to always be responsible and carrying out the duties that become its obligation to be the role of replacing parenting parents at home for 24 hours. Musyrif has the task of assisting students in the dormitory sector in the following activities: 1) Carrying out the work program of the musyrif (boarding trustees). 2) Following the boarding program for guardians. 3) Provide guidance and guidance of Emotional and Spiritual intelligence (Tarbiyah Ruhiyah) to students. 4) Control the development of personality and student learning attitudes. 5) Applying discipline in all aspects of the pesantren based on applicable student rules and regulations. 6) Provide guidance and guidance of skills (skills) that are religious and selfmanagement. 7) Protect students to create peace in the dormitory. 8) Act decisively against violations of the Code of Conduct committed by students. 9) Establish communication with parents / guardians of students. 10) Maintaining assets and all forms of inventory in the hostel. 11) Making periodic and incidental reports to the Board of Trustees of the Board of Trustees.

\section{A. Musyrif Guidance Program in Boarding Schools Middle School}

From the results of the above research the researchers produced the discovery of the musyrif guidance program. each is contained in the Musyrif guidance program component, and is explained as follows:

1. Basic Services of

a. Usbu 'Ruhy Guidance Usbu

Ruhy is an activity for a week in the form of guidance of Ruhiyah through rutinan worship activities such as shaum sunnah, recitations of jama'i tahajjud and alms to form a fond character of worship. with the target set by the hostel manager. 


\section{b. Character Building}

Program Character Bulding is a program designed to form a musyrif characterized by spiritual, moral, independence, leadership and entrepreneurship with various forms of activities both indoors and outdoors.

c. Workshop / training / seminar Workshop / training / seminar

activities are one form of debriefing activities for Musyrif. This activity includes the provision of insight and basic skills of the musyrif including the activities of motivation training, parenting guidance, motivation by bringing in competent sources or experts in accordance with the needs of the hostel and other training activities that support the attainment of the quality of the musyrif.

\section{d. Boarding}

Boarding taklim activities taklim activities in collaboration with the boarding school in providing speakers and taklim materials. Apart from that, the musyrif (boarding trustees) were also involved as taklim and student conditioning

\section{ResponsiveService}

\section{a. Room Visit}

Room visit is a musyrif coaching activity in collaboration with counseling teachers in the form of counseling, heating and feeling check. Counseling is done if there are findings relating to student problems both at school and in the hostel. Healing is a form of mental mentoring effort when students face and learn to solve their problems. While feeling check is a routine musyrif conditioning activity for students in each room during the night before going to sleep in a form such as evaluating daily musyrif activities, sharing discussions with experiences so that musyifs and musyrifahs can monitor student development with each other sharing experiences so that musyrifs can monitor the progress of each student the day of

\section{b. Motivation Force}

Motivation is an activity of fostering the character of the musyrif in the form of giving motivation and tausiyah in turns. This activity aims to shape the character of the leader, discipline, respect for others, love the students, become a substitute role for the role of parents and have the nature of empathy. This activity is carried out according to needs.

c. Dauroh Life Skill

Life skill training (training) activities are carried out according to basic skills for a musyrif in the hostel including life skills cooking, washing, knitting, sewing, flannel creations, cupping, haircut, first aid and or otheractivities life skill that are able to provide benefits and provisions for students.

\section{d. MABIT}

MABIT is an acronym for Malam Bina Iman and Taqwa. This activity is carried out in a full night, accompanied by study of Islam, recitations and tahajud jamai '. This activity aims to form a strong Islamic character and bring the musyrif closer to Allah SWT.

3. Individual Planning

a. Dhikr Ba'da Prayers and Al Matsurat The habit of

dzikir ba'da prayers is done musyrif every day and congregation. Dzikir al-Matsurat is performed in the morning and evening every day. This activity trains and accustoms 
memorized memorization and understands the meaning of each chanting of the dhikr he reads.

b. Muhadhoroh (Speech in Arabic, English and Indonesian)

Muhadhoroh is a refraction of the musyrif in practicing public speaking. The biology is held once a week.

c. Room pickets Room

pickets are routine $\mathrm{K} 5$ activities carried out by designated room members according to the schedule. It aims to practice the responsibility of cleaning and comfort of his room every day by being monitored by the head of the field of cleaning / head of thedormitory

d. Tahaijud prayer

. Tahajud is held once a week and the other day is held independently.

e. Ifthor Jamai

Ifthor jama'i is a joint iftar activity between teachers, musyrif and students every Monday and Thursday. this activity is recommended for all members of the institution in forming and creating discipline, honesty, responsibility, independence, simplicity and cost-effective meals.

f. Clean Sunday

This activity is carried out jointly between Musyrif musyrifah and students in terms of cleanliness of the dormitory environment. This activity aims to build togetherness between the musyrif and students, train cooperation and habituation to healthy life free of disease.

g. Outbound Outbound

activities Molipuli hiking trail adventurers to places that are natural nature, mukhoyyam (camp) and or other supporting activities that train the independence of the musyrif.

4. System documents

System documents are based on managing the activities of the guidance program at boarding school or boarding school. in fact, it is carried out with a performance-based management system in which there is effective supervision and guidance from both the institution and outside the institution. The following are some of the set of performance system document documents for counselors and institutions in managing the mid-level musyrif guidance program at the Boarding School. Document system services include:

a. Development of quality management for As-Syifa SMAIT Boarding School Wanareja

b. Scientific research

c. Planning and evaluating the formation of structural, budget and infrastructure

d. Management of good facilities and infrastructure

\section{Conclusion}

Musyrif and musyrifah guidance programs at boarding schools in secondary level, consisting of a) Basic services, such as ushbu ruhi, weekly recitation, muhadhoroh, tausiyah morning, and seminars / workshops / training. b) Responsive services, such as home \& room visits, force meetings andcycle life skills. c) Individual planning, MABIT, character building, go green, clean pickets. and d) Support systems such as the Musyrif and Musyrifah Guidance Program must still be developed, so special attention and training is needed in creating a midlevel musyrif and guidance boarding school program, the establishment of a boarding 
management structure, the existence of a budget planning guidance program, and developing guarantees the quality of musyrif and musyrifah through research and training, organizing collaborations with other institutions.

\section{Reference}

Alex. (2013). Indonesian dictionary. Jakarta: TAMER Press.

Anwar, F. (2019). The foundation of Islamic Guidance and Counseling. Yogyakarta: CV. Budi Utama. Abas Mansur Tamam (2019) Islamic World View. Jakarta: Spirit media.

Herman. (2019). Musyrif iteraksi with santri in Moral Development in Ar-Risalah college. ArRisalah, http://repository.uinib.ac.id/2434/1/fuull_2.pdf.

Herman. (2019). Musyrif iteraksi with santri in Moral Development in Ar-Risalah college. Thesis of UIN Imam Bonjol, http://repository.uinib.ac.id/2434/1/ fuull_2.pdf.

Masdudi (2008). School Perspective Guidance and Counseling. Cirebon: STAIN Press.

Nata, A. (2016). Islamic Education Innovation. Jakarta: Salemba Diniyah.

Putra, N. (2012). Educational Qualitative Research Methods. Jakarta: RajaGrafindo.

Ramayulis, M. (2016). Islamic Guidance and Counseling in Madrasas and Schools. Jakarta: Kalam Mulia.

Susanto, A. (2018). Guidance and Counseling in Schools. Jakarta: Prenada Media.

Trim, B. (2008). Bambang Trim, Installing Children's Morals. Jakarta: Grafindo Media Pratama. Zamroni, E. (2015). Permendikbud Guidance and Counseling Management No. 111 of 2014. Journal of Gusjigang Counseling, Kudus: FKIP Sunan Muria, https://jurnal.umk.ac.id/index.php/gusjigang/article/view/256/256. 